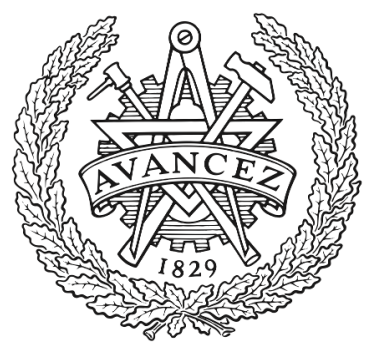

CHALMERS

UNIVERSITY OF TECHNOLOGY

\title{
Ozone pollution will compromise efforts to increase global wheat production
}

Downloaded from: https://research.chalmers.se, 2023-04-26 10:48 UTC

Citation for the original published paper (version of record):

Mills, G., Sharps, K., Simpson, D. et al (2018). Ozone pollution will compromise efforts to increase global wheat production. Global Change Biology, 24(8): 3560-3574.

http://dx.doi.org/10.1111/gcb.14157

N.B. When citing this work, cite the original published paper. 


\title{
Ozone pollution will compromise efforts to increase global wheat production
}

\author{
Gina Mills $^{1,2}$ (1) | Katrina Sharps ${ }^{1}$ | David Simpson ${ }^{3,4} \mid$ Håkan Pleijel $^{2}$ | \\ Malin Broberg $^{2}$ | Johan Uddling ${ }^{2}$ | Fernando Jaramillo5, (D) | William J Davies ${ }^{7}$ | \\ Frank Dentener $^{8}$ | Maurits Van den Berg ${ }^{7}$ | Madhoolika Agrawal ${ }^{9}$ | \\ Shahibhushan B. Agrawal ${ }^{9}$ | Elizabeth A. Ainsworth ${ }^{10}$ | Patrick Büker ${ }^{11}$ | \\ Lisa Emberson $^{11}$ | Zhaozhong Feng ${ }^{12}$ | Harry Harmens ${ }^{1}$ | Felicity Hayes ${ }^{1}$ | \\ Kazuhiko Kobayashi ${ }^{13}$ | Elena Paoletti ${ }^{14}$ (D) | Rita Van Dingenen ${ }^{8}$
}

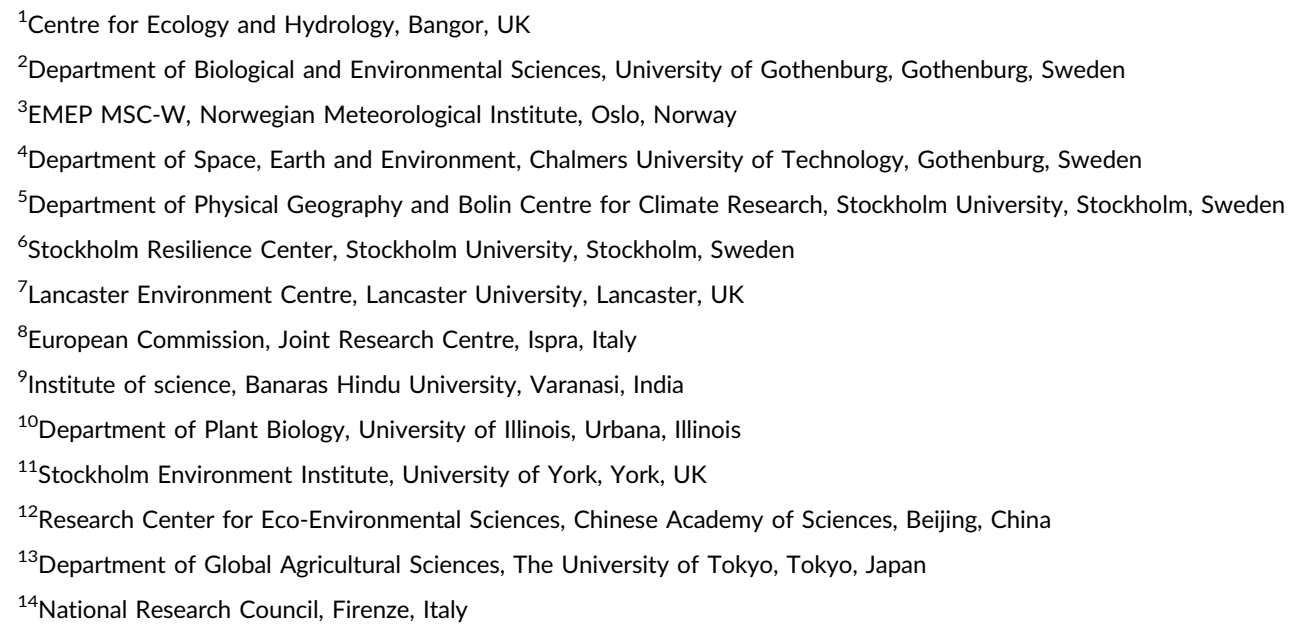

\section{Correspondence}

Gina Mills, Centre for Ecology and Hydrology, Environment Centre Wales, Bangor, UK.

Email: gmi@ceh.ac.uk

Funding information

Adlerbertska Stiftelserna; Natural Environment Research Council, Grant/Award Number: NEC05574, NEC06476, NEC05831; EMEP under UNECE; EU project ECLAIRE, Grant/Award Number: 282910; Research Council of Norway through the NOTUR project EMEP, Grant/Award Number: NN2890K

\begin{abstract}
Introduction of high-performing crop cultivars and crop/soil water management practices that increase the stomatal uptake of carbon dioxide and photosynthesis will be instrumental in realizing the United Nations Sustainable Development Goal (SDG) of achieving food security. To date, however, global assessments of how to increase crop yield have failed to consider the negative effects of tropospheric ozone, a gaseous pollutant that enters the leaf stomatal pores of plants along with carbon dioxide, and is increasing in concentration globally, particularly in rapidly developing countries. Earlier studies have simply estimated that the largest effects are in the areas with the highest ozone concentrations. Using a modelling method that accounts for the effects of soil moisture deficit and meteorological factors on the stomatal uptake of ozone, we show for the first time that ozone impacts on wheat yield are particularly large in humid rain-fed and irrigated areas of major
\end{abstract}


wheat-producing countries (e.g. United States, France, India, China and Russia). Averaged over 2010-2012, we estimate that ozone reduces wheat yields by a mean $9.9 \%$ in the northern hemisphere and $6.2 \%$ in the southern hemisphere, corresponding to some $85 \mathrm{Tg}$ (million tonnes) of lost grain. Total production losses in developing countries receiving Official Development Assistance are 50\% higher than those in developed countries, potentially reducing the possibility of achieving UN SDG2. Crucially, our analysis shows that ozone could reduce the potential yield benefits of increasing irrigation usage in response to climate change because added irrigation increases the uptake and subsequent negative effects of the pollutant. We show that mitigation of air pollution in a changing climate could play a vital role in achieving the above-mentioned UN SDG, while also contributing to other SDGs related to human health and well-being, ecosystems and climate change.

\section{KEYWORDS}

climate change, developed countries, developing countries, food security, irrigation, ozone, stomatal uptake, wheat, yield

\section{$1 \mid$ INTRODUCTION}

Tropospheric (or ground-level) concentrations of ozone, a photochemically produced secondary pollutant for which the precursors include oxides of nitrogen, volatile organic compounds and carbon monoxide (Simpson, Arneth, Mills, Solberg, \& Uddling, 2014), are already high in many crop-growing areas of the world, e.g. in North America, Europe, and South and East Asia (Cooper et al., 2014; Mills et al., 2018; Wild et al., 2012). Concentrations are increasing rapidly in developing countries and are predicted to continue to increase in coming decades unless suitably ambitious measures are taken to cut precursor emissions (Cooper et al., 2014; Wild et al., 2012). Ozone damages sensitive crops such as wheat, rice and soybean (Grünhage et al., 2012; Mills et al., 2007) by diffusing into the leaves through the stomatal pores and reacting with biomolecules inside the leaf to form reactive oxygen species, thereby triggering metabolically expensive defence mechanisms, promoting leaf senescence and diverting resources away from growth and seed production (Ainsworth, 2016). Despite this, developing ways to mitigate the damaging effects of ozone pollution has attracted little attention from agronomists and policy makers investigating ways to increase yields in our changing climate. As well as quantifying the effects of ozone on yield in different climatic regions of the world, we investigate how some management and breeding approaches may actually exacerbate the effects of ozone by promoting greater ingress of the pollutant into leaves, thus leading to increased yield losses on a global scale. We focus on quantifying the impacts of ozone on the yields of wheat, a crop that provides $20 \%$ of human dietary protein and calorific intake globally (Shiferaw et al., 2013).

In striving to attain the United Nations Sustainable Development Goal 2 (UN SDG2) of "ending hunger, achieving food security and improved nutrition, and promoting sustainable agriculture" by 2030 (UN SDG, 2016), it is anticipated that considerably greater production of grain crops such as wheat will be required (International Food
Policy Research institute, 2016). With global wheat demand doubling since 1980 and yields stabilizing in many wheat-producing countries (Brisson et al., 2010; Shiferaw et al., 2013), a multidisciplinary approach is needed if substantial increases in production are to be achieved in coming decades (Hawkesford et al., 2013). Changes in crop management such as increasing water availability through water harvesting, improved irrigation efficiency and expanding irrigation infrastructure (Balkovič et al., 2014; Jägermeyr et al., 2016; Mueller et al., 2012) could provide substantial progress towards closing the gap between maximum possible yields and actual yields in the field. While such approaches have the benefit of increasing stomatal uptake of $\mathrm{CO}_{2}$ thereby enhancing photosynthesis (Roche, 2015), a simultaneous increase in the uptake of ozone (Ainsworth, 2016; Wilkinson, Mills, Illidge, \& Davies, 2012) might result in greater negative impacts of ozone and counteract some of the benefits. Others are focusing on increasing wheat yield via breeding programmes targeted at desirable traits such as higher photosynthesis, greater photosynthate partitioning to the seeds and higher nutrient use efficiency, or increased tolerance to biotic and abiotic stresses such as fungal diseases, heat and drought stress (Hawkesford et al., 2013; International Food Policy Research Institute, 2016; Shiferaw et al., 2013). Currently, ozone tolerance is not yet included as a desirable trait in crop breeding schemes (Ainsworth, 2016; Frei, 2015; Lobell \& Gourdji, 2012). Indeed, recently released high-yielding wheat varieties tend to be more sensitive to ozone than the older varieties, in part explained by their higher stomatal conductance (Biswas et al., 2009).

Earlier studies using dose-response relationships based only on the atmospheric concentration of ozone simply predict that the highest effects are likely in the areas with the highest ozone concentrations. Such studies indicated that in the year 2000 , ozone pollution reduced global wheat yield by $12 \%-15 \%$, with mean losses in the range of $16 \%-27 \%$ in countries of South and East Asia (Avnery, Mauzerall, Liu, \& Horowitz, 2011a; Teixeira et al., 2011; Van Dingenen et al., 2009). 
One follow-on study predicted that these global losses would increase to $25.8 \%$ by 2030 , with $44.4 \%$ and $25.7 \%$ losses in South and East Asia, respectively (Avnery, Mauzerall, Liu, \& Horowitz, 2011b). However, these studies did not take into account factors affecting the stomatal uptake of ozone, which casts some doubt on the accuracy of their assessments of global wheat yield losses and the spatial distribution of these losses. Since stomatal conductance and ozone flux differ significantly between humid and arid climates even when concentrations are the same (being higher in the former), marked differences might be anticipated in estimates of the spatial distribution of ozone impacts derived using a concentration-based methodology vs. a stomatal uptake-based methodology. We now know that the field effects of ozone are far better correlated with stomatal ozone uptake than with ozone concentration (Mills et al., 2011), and a stomatal uptake-yield effect relationship has been developed for wheat using data from experiments conducted in several countries (Grünhage et al., 2012).

A recent meta-analysis investigated the effects of ambient ozone on wheat by comparing yields in field-based open-top chambers (OTCs) ventilated with ambient air, with those in OTCs ventilated with filtered air that reduced the ozone concentration by on average $62 \%$, effectively achieving preindustrial concentrations (Pleijel, Broberg, Uddling, \& Mills, 2018). Based on results from 33 experiments (from nine countries, three continents using 17 cultivars plus one set of four cultivars), the average yield loss associated with reducing the mean ozone concentration from 35.6 to 13.7 ppb was $8.4 \%$, with the starch and protein yield reduced by $10.9 \%$ and $6.2 \%$, respectively. In the same meta-analysis, relative grain yield loss increased linearly as ozone concentration increased, with the highest losses being in the $20 \%$ $30 \%$ range for some sites in India, China and the United States (calculated from supplementary data in Pleijel et al., 2018). Despite such compelling field evidence of the negative effects of ozone on crop yields, most statistical and process-based modelling of future crop yields are not yet including the impacts of current or predicted future ozone pollution (Challinor, Ewert, Arnold, Simelton, \& Fraser, 2009; Emberson et al., 2018; Lobell \& Asseng, 2017; Lobell \& Gourdji, 2012).

We undertook this study to highlight the potential yield gains that could be made on the global scale from either reducing ozone concentrations and/or developing crop management or crop breeding approaches to reduce the negative effects of the pollutant. We consider effects in major exporters such as the United States, France, Canada and Australia as well as in countries such as India, China, and Pakistan that have a high dependency on national crop production and imports to feed rapidly expanding populations (FAOSTAT). Our results are also considered separately for developed countries (DC) and developing countries receiving Official Development Assistance (ODA; OECD, 2017). For the first time, we quantify the potential additional negative effects of ozone that could develop if irrigation is used to offset the negative effects of current and future rainfall shortages. In doing so, we tested the hypotheses that: (i) total wheat production losses due to ozone are higher in developing than developed countries; (ii) the largest impacts of ozone in major wheat-producing countries occur in humid climates or in drier regions with high irrigation usage; and (iii) future strategies to increase wheat yield and help feed the growing global population by increasing crop stomatal conductance, such as through crop breeding and additional irrigation, may exacerbate the negative effects of ozone pollution, especially in drier climates. We have used an empirical approach to test these hypotheses, involving spatial modelling of the cumulative stomatal uptake of ozone and concentration-based metrics for crop relevant time periods and application of dose-response relationships derived from field-based experiments to determine the extent of effect on yield per $1^{\circ} \times 1^{\circ}$ grid square.

\section{MATERIALS AND METHODS}

\section{1 | Agricultural data}

Modelled global wheat production data were downloaded from the GAEZ (Global Agro-Ecological Zones) database which has been developed by the Food and Agricultural Organisation of the United Nations (FAO) and the International Institute for Applied Systems Analysis (IIASA) to assess agricultural resources. Modelled values are derived in the database from the downscaling of FAO national production data, crop distribution data and AEZ crop suitability layers, for each country. Irrigated and rain-fed wheat production data for the year 2000 in $\mathrm{Mg}$ (tonnes) per cell was acquired for this study from the GAEZ data portal v. 3 in raster format at 5 arc minute $\left(0.0833^{\circ}\right)$ spatial resolution (Figure S1a). A global $1^{\circ} \times 1^{\circ}$ grid was created using ArcGIS v. 10.1 (Environmental Systems Research Institute, Redlands, CA, USA) and wheat production was summed per cell. To estimate production per grid cell in 2010-2012 from the year 2000 grid cell data, a conversion factor was derived for each country by dividing the average total wheat production over the period 2010-2012 by that from 19992001, using country totals downloaded from FAOSTAT. Only cells where the summed wheat production was $>500 \mathrm{Mg}$ were included.

\subsection{Global ozone concentration and stomatal uptake}

The EMEP MSC-W (European Monitoring and Evaluation Programme, Meteorological Synthesising Centre-West) chemical transport model, version 4.8 (Simpson, Ashmore, Emberson, \& Tuovinen, 2007; Simpson, Tsyro, \& Wind, 2015; Simpson et al., 2012) was used to model ozone concentration and stomatal uptake on a global scale at a $1^{\circ} \times 1^{\circ}$ resolution. This $3-\mathrm{D}$ model is used for air quality assessments and has 20 vertical layers extending from the ground to $100 \mathrm{hPa}$, using terrain-following coordinates, and makes use of a chemical scheme involving 137 reactions. Meteorological data, including a soil moisture index (SMI), are taken from the European Centre for Medium Range Weather Forecasting Integrated Forecasting System (ECMWF-IFS) model. The SMI is calculated from the modelled soil water content and the difference between the field capacity (FC) and permanent wilting point (PWP) of the vegetation at a soil depth of 0.28-1 m (Simpson et al., 2012).

Calculations of stomatal ozone uptake make use of the $\mathrm{DO}_{3} \mathrm{SE}$ (Deposition of Ozone for Stomatal Exchange) stomatal conductance 
algorithm that is dependent on variables such as temperature, irradiance, vapour pressure deficit and soil moisture (Büker et al., 2012; Emberson, Ashmore, Simpson, Tuovinen, \& Cambridge, 2001; Simpson et al., 2007, 2012, 2015) in conjunction with an ecosystem-specific calculation of vertical ozone profiles down to canopy surface (Simpson et al., 2012, 2015). The 90 days $7 \mathrm{hr}$ mean ozone concentration (M7, mean of 09:00 to 16:00), 90 days AOT40 (accumulation of ozone hourly mean concentration over $40 \mathrm{ppb}$ during daylight hours) and 90 days POD $_{3}$ IAM (Phytotoxic Ozone Dose above $3 \mathrm{nmol} \mathrm{m}{ }^{-2} \mathrm{sec}^{-1}$, model adapted for large-scale Integrated Assessment Modelling) were calculated from modelled hourly stomatal uptake and accumulated during daylight hours. The latter using the parameterizations defined in the Long-range Transboundary Air Pollution (LRTAP) Convention's Modelling and Mapping Manual (LRTAP Convention, 2017). $\mathrm{POD}_{3} \mathrm{IAM}, \mathrm{M} 7$ and AOT40 were modelled for climatic zone-specific 90-day periods (described later) for 2010, 2011 and 2012 and averaged for this study. M7 and AOT40 were chosen for comparison with $\mathrm{POD}_{3} \mathrm{IAM}$ because they have been widely used in previous concentration-based global and regional impact assessments (e.g. Avnery et al., 2011a, 2011b; Tang, Takigawa, Liu, Zhu, \& Kobayashi, 2013; Van Dingenen et al., 2009) and AOT40-based critical levels are applied in the 51 Parties (countries) of the LRTAP Convention (LRTAP Convention, 2017).

\section{3 | Dose-response relationships}

To determine the effects of $\mathrm{POD}_{3} \mathrm{IAM}, \mathrm{M7}$ and $\mathrm{AOT} 40$ on wheat productivity, response functions were derived for the effect of each metric on wheat yield based on experimental data from open-top chamber experiments conducted in the field in Finland, Sweden, Belgium and Italy (described in Grünhage et al., 2012; Figure S2). Ozone concentration metrics were derived for the hourly mean data for each experiment, while $\mathrm{POD}_{3} \mathrm{IAM}$ was estimated from air humidity (vapour pressure deficit), temperature, solar radiation and soil moisture content using the $\mathrm{DO}_{3} \mathrm{SE}$ model stomatal algorithm (LRTAP Convention, 2017). The parametrization of the wheat stomatal uptake model was tested with respect to observed data (Grünhage et al., 2012). To derive the response functions, data were first standardized for each set of experimental data by linear regression of the yield against the metric used; this function was then used to determine the yield at zero value for the metric (Fuhrer, 1994). The latter was then used to calculate relative yield (RY), with zero $\mathrm{POD}_{3} \mathrm{IAM}, \mathrm{AOT} 40$ or M7 having an RY of 1 , and negative effects of ozone treatments having an $\mathrm{RY}$ of $<1$. Data sets were combined across experiments by plotting all RY against the treatment values for each metric, and linear regression was used to derive yield response functions for $\mathrm{POD}_{3} \mathrm{IAM}, \mathrm{AOT} 40$ and $\mathrm{M7}$ (Figure S2).

\subsection{Global maps of wheat yield loss}

Using the global $1^{\circ} \times 1^{\circ}$ grid wheat production map aligned with the EMEP grid, each cell was assigned to a climatic zone, using the global "Climatic Zone" GIS raster layer produced by the European
Soil Data Centre (ESDAC) at JRC (Joint Research Centre). These climatic zones are based on the classification of the Intergovernmental Panel on Climate Change (IPCC, 2006), with zones defined using a set of rules, which includes annual mean daily temperature, total annual precipitation, total annual potential evapotranspiration and elevation. Cells including more than one climatic zone were assigned to the zone covering the majority of the cell. The spatial distribution of the climatic zones is illustrated in Figure S1b.

A 90-day period for accumulation for each metric was derived for each climatic zone and hemisphere combination and assigned to each $1^{\circ} \times 1^{\circ}$ cell (Table S1). The time period was back projected from 2 weeks before harvest and includes the ozone-sensitive period between anthesis and end of grain fill (Soja et al., 2000) with the time period reflecting the most common growth cycle for that climate (e.g. for winter rather than spring wheat in NW Europe). The harvest date per climatic zone was established by overlaying maps produced by the USDA Major World Crop Areas and Climate Profiles (MWCACP; http://www.usda.gov/oce/weather/pubs/Other/ MWCACP/index.htm) with climatic zones, and checking data with a previous study (Sacks, Deryng, Foley, \& Ramankutty, 2010) and web-based national sources for representative countries per climatic zone. Some climatic zones were merged for simplification and subdivisions were added for cool-temperate climates $0-30^{\circ}$ south and $>30^{\circ}$ south to account for variations in growth cycles for climates that span a large geographical area.

Percentage yield loss and production loss was calculated per grid cell relative to zero $\mathrm{POD}_{3} \mathrm{IAM}$ or AOT40 to represent a clean air situation with ozone concentrations reduced to close to preindustrial levels (Cooper et al., 2014; Royal Society, 2008), or 25 ppb M7 to facilitate comparison with an M7-based earlier study (Van Dingenen et al., 2009). For $\mathrm{POD}_{3} \mathrm{IAM}$, effects were determined separately per $1^{\circ} \times 1^{\circ}$ grid cell using (i) $\mathrm{POD}_{3} \mathrm{IAM}$ values that were weighted by the proportion of irrigated and rain-fed wheat production in the cell and (ii) $\mathrm{POD}_{3} \mathrm{IAM}$ values representing full use of irrigation by assuming that soil moisture was not limiting to ozone uptake.

The impacts of ozone were analysed by country, climatic region and countries assigned by the Organisation for Economic Co-operation and Development (OECD) Development Assistance Committee (DAC) into the following categories receiving Official Development Assistance (ODA): Least Developed Countries (LDC); Other Low Income Countries (OLIC), Lower Middle Income Countries and Territories (LMIC); and Upper Middle Income Countries and Territories (UMIC). The countries included in these categories are listed in OECD (2017), with their designation indicated in Table S2. For comparison, effects of ozone on wheat yield are also described for developed countries (DC), assumed here to be all other countries that are not included in the ODA recipients list.

\subsection{Evaluation of modelled ozone concentration and stomatal uptake}

EMEP model results were evaluated against observational data from the Global Atmosphere Watch (GAW) stations (Schultz et al., 2015). 
In order to obtain relevant comparisons for ozone at rural locations (and not mountain tops), the data were tested by two criteria: (i) relative height (hRel) and (ii) a diurnal variation index (DVI). The hRel calculation used an estimate of the height of the station relative to the height of the lowest terrain within $5 \mathrm{~km}$ radius (following Loibl, Winiwarter, Kopsca, Zufger, \& Baumann, 1994; Klingberg et al., 2012) using global topographic data from the ETOPO1 database (Amante \& Eakins, 2009). The DVI reflects the fact that mountaintop stations show hardly any variation from day to night (Klingberg et al., 2012) and was derived by first calculating the average concentration for each hour of the day over the year, and then calculating the ratio of the maximum mean-hourly value to the daily means. We used the criteria that hRel should be less than $100 \mathrm{~m}$, and DVI $>1.04$. Modelled ozone concentrations were also tested against time series for measured concentrations at representative GAW stations from sites in Argentina, Canada, Germany, Ireland, Japan and the United States. We were unable to test our analysis for countries such as China or India because of the lack of suitable publically available climate and ozone data.

To test the validity of the stomatal uptake component of the model, spatial variation in $\mathrm{POD}_{3} \mathrm{IAM}$ was compared with variation in the ratio of actual evapotranspiration (AET) to potential evapotranspiration (PET) across the United States. The rationale for this is that stomatal conductance is a key regulator of land-atmosphere gas exchange, controlling fluxes of both ozone and water vapour (and thus AET). Satellite data were compiled using the annual raster global data sets of AET and PET from the MODIS Evapotranspiration Data Product MOD16A3 (Mu, Zhao, \& Running, 2011) available from the NASA's Numerical Terradynamic Simulation Group (NTSG) server. These data were calculated using an algorithm based on the Penman-Monteith equation (Monteith, 1965). AET was divided by the corresponding PET value for each cell of the $1 \mathrm{~km}^{2}$ grid for each of the years 2010, 2011 and 2012 where the land area dedicated to wheat production exceeded $10 \%$. Thereafter, we obtained the arithmetic annual mean of the 3 years per cell. The area-weighted mean AET/PET for each of the $1^{\circ} \times 1^{\circ}$ cells previously created as described above for wheat production was calculated. This was plotted against the 3-year mean $\mathrm{POD}_{3} \mathrm{IAM}$ (including soil moisture limitation) divided by $\mathrm{M} 7$ for the 90 -day accumulation period to provide an indication of the integrated growing season stomatal conductance, without the confounding influence of the ozone concentration. A similar analysis was conducted using AET/PET divided by leaf area index (LAI), with spatial LAI data taken from the MODIS Leaf Area Index/FPAR product (Myneni, Knyazikhin, \& Park, 2015). This was done to separate the influence of LAl from that of stomatal conductance, since both control AET.

\section{3 | RESULTS}

\section{1 | Model validation}

Before consideration of the results of this analysis, three approaches were used to test the validity of the stomatal uptake modelling.
Firstly, time series of the daily maximum hourly mean ozone concentration (Dmax) data were compared with modelled data for sites from the global GAW network to illustrate the model performance during the times of peak ozone each day. Over the course of a year, the EMEP model captured the spatial and temporal variations across the regions, including the seasons with higher concentrations and longer ozone episodes (Figure S3). Secondly, we tested how well the model estimated Dmax and M7 at all of the GAW stations for 2012, which satisfied the hRel and DVI criteria (Figure S4). The red points and lines are for the complete data set, while the black data and lines are for the same data after exclusion of outliers. This procedure was followed since all global data sets are subject to errors in the data reporting and collection, and not all sites are equally representative for their surrounding area. Figure S4 shows a very good correlation between the modelled and observed values $\left(r^{2}\right.$ ranges from .88 to .95 ), with rather little scatter considering the large geographical network. Thirdly, we tested how well the model estimated stomatal conductance by focusing on data for the wheat-growing areas of the United States for which satellite data for the ratio of AET to PET is available. We found that there is a strong correlation between $\mathrm{AET} / \mathrm{PET}$ and $\mathrm{POD}_{3} \mathrm{IAM} / \mathrm{M7}\left(r^{2}=.63, p<.001\right.$, Figure S5). Also $\mathrm{AET} /(\mathrm{PET} \times \mathrm{LAI})$ was significantly, but less strongly, correlated with $\mathrm{POD}_{3} \mathrm{IAM} / \mathrm{M7}$ ( $p=.039$, data not shown). The AET/(PET $\times$ LAI) index reflects stomatal control of AET since the additional influence of LAI has been accounted for. From these results, we gained confidence that our new modelling approach for estimating the effects of ozone on yield based on stomatal uptake could be used at the global scale.

\subsection{Comparison of current yield effects using AOT40, $\mathrm{M7}$ and $\mathrm{POD}_{3} \mathrm{IAM}$}

For comparison with earlier studies, we first examined the extent to which the magnitude and spatial variation of yield loss estimates based on the stomatal uptake approach used here differ from those based on the concentration of ozone using AOT40 and M7, using data averaged for 2010-2012. The spatial distributions for AOT40 and $\mathrm{M7}$ are fairly similar, with the highest values being in the western half of the United States, northern half of India and Pakistan, northern and western China and parts of Turkey (Figure 1a,b). However, the grid square values for $\mathrm{POD}_{3} \mathrm{IAM}$, weighted by the proportion of irrigation in use, provide a different spatial pattern, with clearly defined areas of high $\mathrm{POD}_{3}$ IAM in the eastern half of the United States, Mediterranean areas, central Europe, parts of India, Pakistan and western and southern China (Figure 1c).

Globally, the mean percentage yield losses in the wheat-growing areas are $13.8 \%, 13.4 \%$ and $9.4 \%$ for $A O T 40, M 7$ and $\mathrm{POD}_{3} \mid \mathrm{AM}$ respectively (Table S2). Thus, loss estimates suggested by the older concentration-based methods are similar and more than one-third higher, on average than those obtained from our stomatal uptake modelling using $\mathrm{POD}_{3} \mathrm{IAM}$. In the top wheat-producing countries, China and India, yield loss estimations using AOT40 of $25 \%$ and $21.5 \%$ respectively are around double those estimated using 


\section{Ozone}

Yield loss (\%)

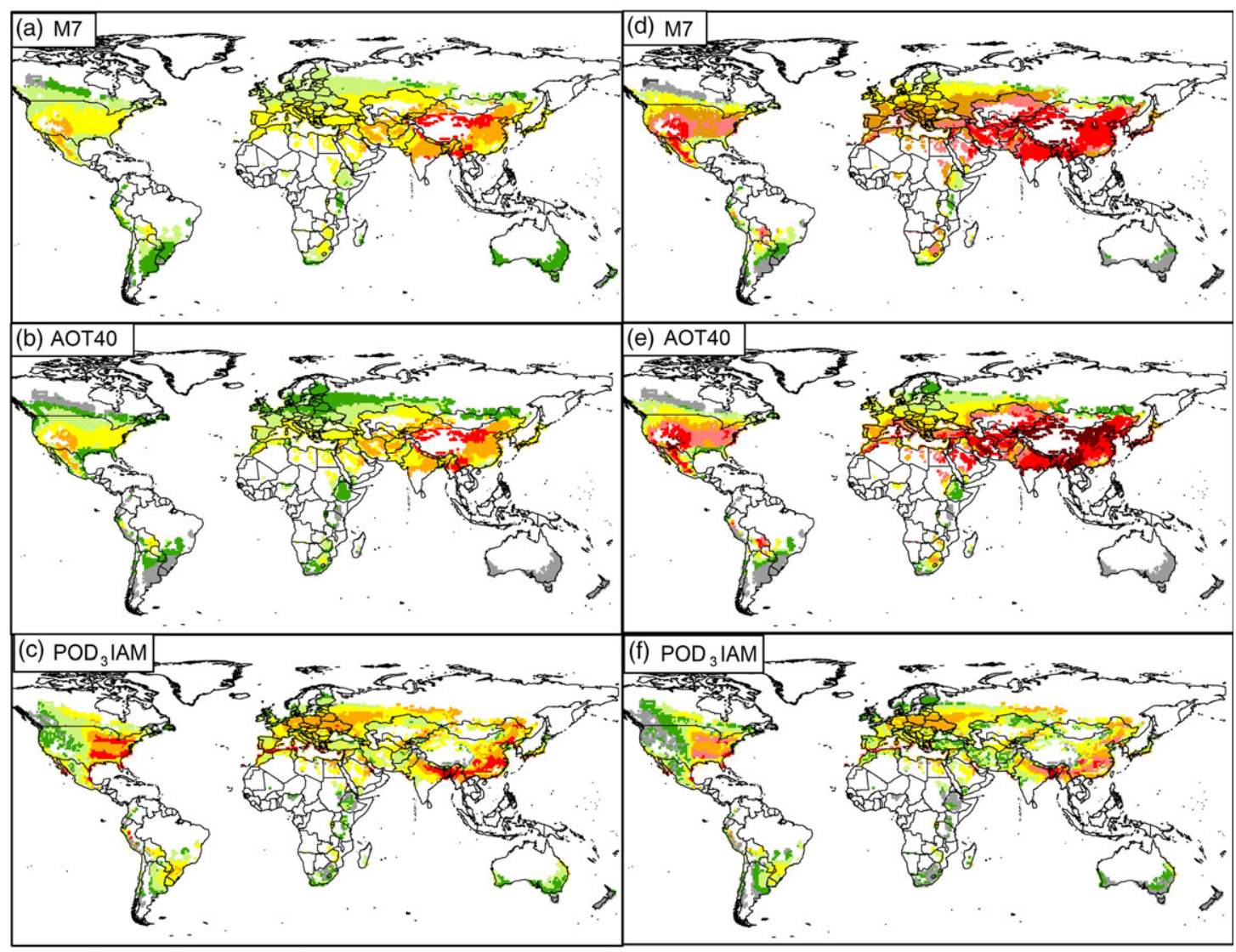

\section{Ozone map categories}

\begin{tabular}{lllllllll} 
& & & & & & & \\
$\begin{array}{l}\mathrm{M} 7 \\
(\mathrm{ppb})\end{array}$ & 0 & 30 & 40 & 50 & 60 & 70 & 100 \\
$\begin{array}{l}\mathrm{AOT} 40 \\
(\mathrm{ppm} h)\end{array}$ & 0 & 2 & 8 & 12 & 20 & 30 & 60 \\
$\begin{array}{l}\mathrm{POD} / \mathrm{AM} \\
\left(\mathrm{mmol} / \mathrm{m}^{-2}\right)\end{array}$ & 0 & 2 & 5 & 10 & 15 & 20 & 35 \\
\hline
\end{tabular}

FIGURE 1 (a)-(c) The seasonal mean M7 (ppb), AOT40 (ppb hr) and POD $\mathrm{PIM}_{3}\left(\mathrm{mmol} / \mathrm{m}^{2}\right)$ and (d)-(f), the negative effects of ozone pollution on wheat yield presented as the $\%$ yield loss for M7, AOT40 and $\mathrm{POD}_{3} \mathrm{IAM}$. All values are the means per $1^{\circ} \times 1^{\circ}$ grid cell where the wheat production exceeds $500 \mathrm{Mg}$ and are averaged for 2010-2012. Values for (c) $P_{0} D_{3} \mid A M$ and (f) yield loss calculated from $P O D_{3} \mid A M$ use the $\mathrm{POD}_{3} \mid \mathrm{AM}$ weighted by the proportion of production in the cell that is rain-fed (using $\mathrm{POD}_{3} \mid \mathrm{AM}$ calculated using soil moisture limitation) and irrigated (using $\mathrm{POD}_{3} \mathrm{IAM}$ calculated without soil moisture limitation). Yield losses for $\mathrm{AOT} 40$ and $\mathrm{POD}_{3} \mathrm{IAM}$ are relative to 0 ppm hr and $0 \mathrm{mmol} / \mathrm{m}^{2}$ respectively, while those for $\mathrm{M} 7$ are relative to $25 \mathrm{ppb}$

$\mathrm{POD}_{3} \mathrm{IAM}(11.7 \%$ and $12.2 \%$ respectively), while in other high wheat-producing countries such as Russia and Canada, percentage yield losses are similar using both metrics (averaging 10.6\% and $7.4 \%$ respectively).

There are also spatial differences within countries of the areas estimated to have the highest losses determined using the different approaches (Figure 1). For example, using concentration-based approaches, estimated yield losses in the United States are 17.2\%$19.8 \%$ in western warm-temperate-dry climates (AOT40 of $18.5 \mathrm{ppm}$ hr, M7 of $58.1 \mathrm{ppb}$ ) but only $14.8 \%-15.5 \%$ in eastern warm-temperate-moist climates (AOT40 13.8 ppm hr, M7 53.5 ppb). In contrast, the stomatal uptake approach estimates that conditions are less conducive to ozone uptake in the hotter, drier western areas, where ozone concentrations are higher but irrigation is used on less than $50 \%$ of fields, resulting in a lower mean yield loss of 8.2\%. In the wetter eastern states, where more humid conditions promote plant ozone uptake, yield loss is estimated to be $13.9 \%$. Similarly, using concentration-based metrics, high yield losses are estimated in central states of India (range 17.5\%-55\% yield loss, Figure $1 \mathrm{~d}, \mathrm{e})$. However, estimations based on stomatal uptake shift the 
region of greatest risk to the northern and north-eastern states of India, such as Uttar Pradesh and Bihar, where climatic conditions and abundant ozone pollution are highly conducive to ozone uptake, inducing yield losses in the range 12.5\%-17.5\% (Figure 1f).

On a global scale, production losses estimated using $\mathrm{POD}_{3} \mathrm{IAM}$ (85.2 $\mathrm{Tg}$, where $1 \mathrm{Tg}=1$ million tonnes) are smaller than estimated using M7 (122 Tg) or AOT40 (127 Tg) (Table S2, Figures 2 and S6). These differences are particularly large for countries such as India and China, where production losses of 13 and $18 \mathrm{Tg}$ respectively are estimated using $\mathrm{POD}_{3} \mathrm{IAM}$, compared to losses in the range 20 $21 \mathrm{Tg}$ and 32-39 $\mathrm{Tg}$, respectively, for concentration-based indices.

\section{3 | Yield and production losses estimated using $\mathrm{POD}_{3}$ IAM (2010-2012)}

Our analysis also shows that the mean estimated yield losses in the Northern Hemisphere $(\mathrm{NH}, 9.9 \%)$ are greater than those in the Southern Hemisphere ( $\mathrm{SH}, 6.2 \%)$, where ozone concentrations are lower (Figure 1, Table S2). The highest mean percentage yield losses are associated with warm-temperate-moist (12.5\%), tropical-moist (12.6\%) and tropical-wet (17.2\%) climates of the $\mathrm{NH}$ (Figure 3a). Drier $\mathrm{NH}$ climates have relatively similar, but smaller yield losses, including for boreal-dry (10.1\%), cool-temperate-dry (9.3\%) and warm-temperate-dry (10.1\%) climates. In the $\mathrm{SH}$, the greatest losses are found in tropical climates, with mean yield losses being $7.1 \%$, $9.2 \%$ and $6.7 \%$ in tropical-dry, tropical-moist and tropical-montane climates respectively (Figure $3 b$ ). Here, the lowest percentage yield losses are in the cool-temperate-dry and cool-temperate-moist climates (both with a mean of $2.1 \%$ ), with intermediate yield losses in warm-temperate-dry and warm-temperate-moist climates of $4.9 \%$ and $6.3 \%$ respectively.

Globally, 39.7\% of the lost production occurs in DC (Developed Countries), $31.8 \%$ in UMICs (Upper Middle Income Countries and
Territories) and $26.8 \%$ in LMICs (Lower Middle Income Countries and Territories, Figure 4). Mean percentage yield losses are highest for LMIC at $10.7 \%$, followed by $9.5 \%$ for UMIC and $9.1 \%$ for DC. Yield losses in the highest wheat-producing LMICs of India, Pakistan, Egypt and Ukraine are estimated to be $12.2 \%, 9.5 \%, 10.9 \%$ and $12.9 \%$ respectively amounting to $20.4 \mathrm{Tg}$ of lost grain (Table S2). Of the highest wheat-producing UMICs, mean yield losses due to ozone are estimated to be $11.7 \%, 8.2 \%, 9.1 \%$ and $6.0 \%$ for China, Turkey, Kazakhstan and Argentina, respectively, totalling 22.2 Tg of lost production.

This analysis also shows that some of the highest percentage yield losses occur in the top wheat-producing countries of the world such as China, India, United States and Russia (11.7\%, 12.2\%, 10.1\% and $10.8 \%$ respectively), which corresponds to $45 \mathrm{Tg}$ of lost grain yield (Figure 5). For these countries, the greatest within-country production losses are in the warm-temperate-dry climatic regions of China (12.8 Tg) and the tropical-dry-climates of India (8.8 Tg), where $>80 \%$ of the wheat is irrigated (Figure S7). In the United States and France, the greatest yield losses are in areas with warm-temperatemoist climates where irrigation usage is $5.1 \%$ and $24.7 \%$ respectively, while in Russia and Germany the largest losses are in cooltemperate-moist climates with relatively little irrigation usage $\mathbf{( 7 . 7 \%}$ and $7.8 \%$ respectively).

\subsection{Additional yield losses associated with increased use of irrigation}

We found that the ozone penalty for yield is intensified in all climatic zones where a high proportion of wheat is currently rain-fed, if fully irrigated conditions are simulated to provide nonlimiting soil moisture conditions (Figure 6). The total additional production losses would be highest in DCs and UMICs (totalling 1.8 and $1.2 \mathrm{Tg}$, respectively, Figure 7). In LMICs, total additional losses would be

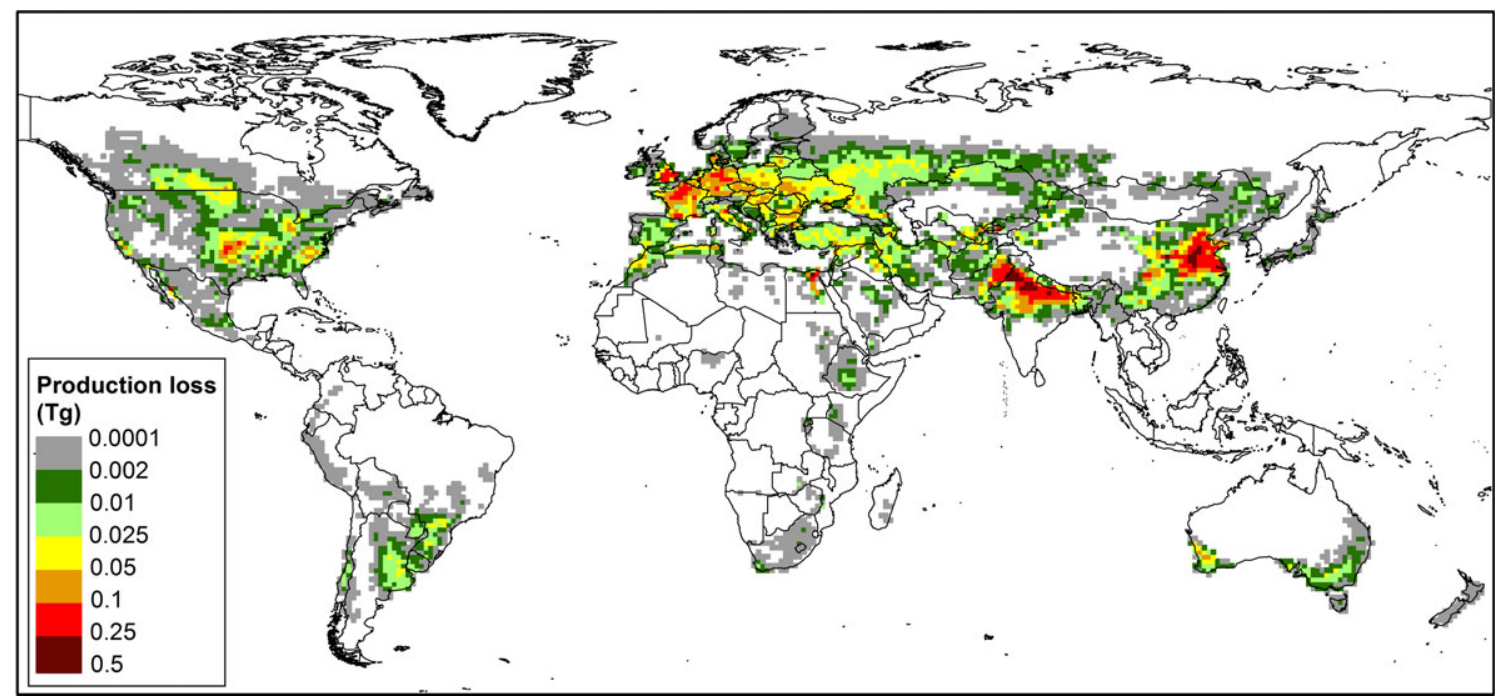

FIGURE 2 Production loss for wheat due to ozone modelled from the $\mathrm{POD}_{3} \mathrm{IAM}$ and percentage yield losses presented in Figure 1 and averaged for 2010-2012 
FIGURE 3 Box plot of percentage yield loss by climatic zone for the (a) northern $(\mathrm{NH})$ and (b) southern hemisphere (SH), calculated using $\mathrm{POD}_{3} \mathrm{IAM}$ as indicated in Figure 1. The box represents the interquartile range, with the top line being the third quartile (Q3), the middle line the median and the bottom line the first quartile (Q1), with the whiskers indicating the range of the data calculated as an upper limit of Q3 + 1.5 (Q3 - Q1) and a lower limit of Q1 - 1.5 (Q3 - Q1), and * representing outliers
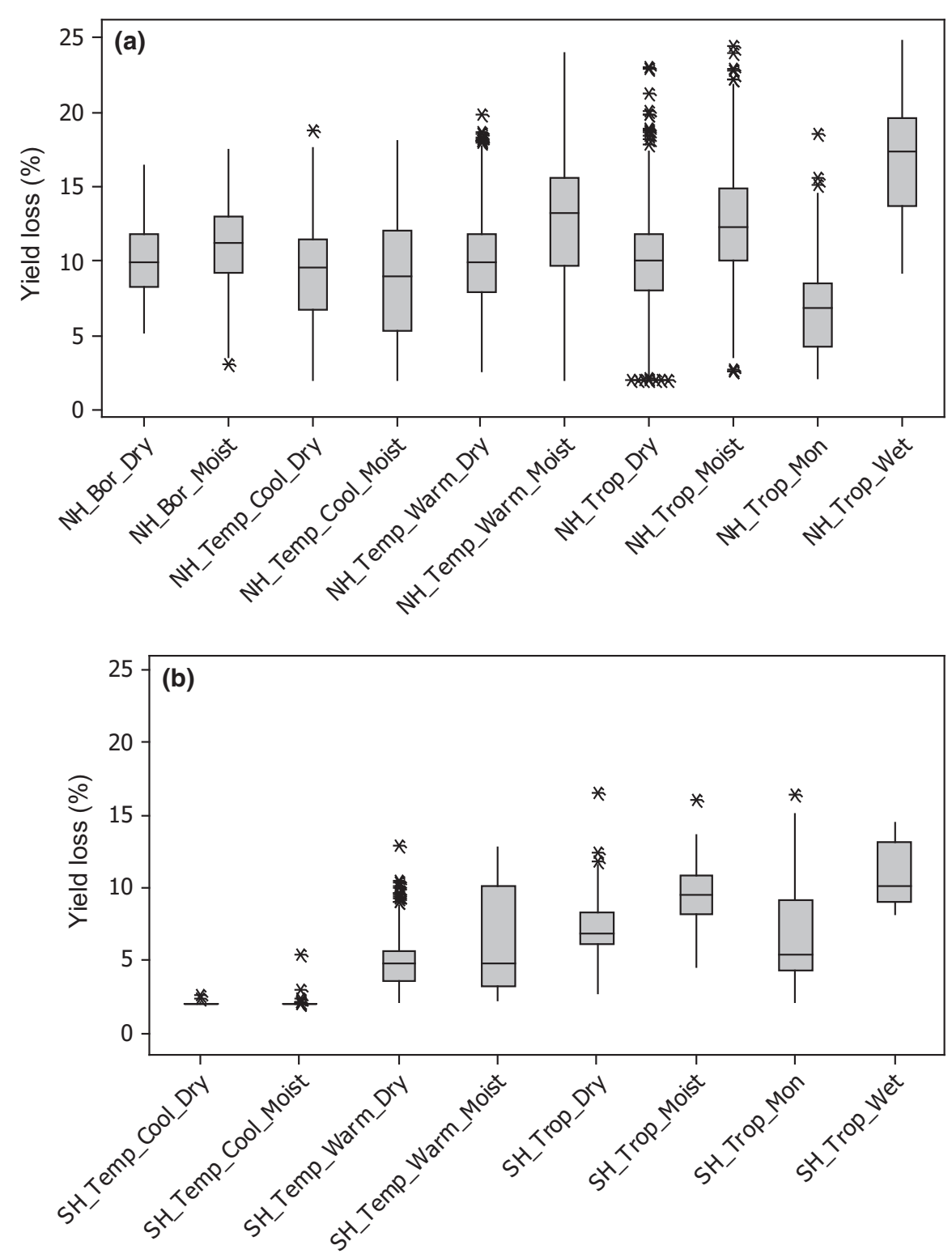

lower at $0.3 \mathrm{Tg}$, in part reflecting the already high proportion of irrigated production in the two highest wheat-producing LMICs, India and Pakistan (73.8\% and $86.4 \%$ respectively).

Additional yield losses would be greatest in drier climates where soil moisture is limiting ozone uptake, especially where irrigation use is currently $<50 \%$ (Figures 8 and S8). For example, nearly one Tg of additional yield losses would occur in the drier temperate climates of the United States (Figure 8), three-quarters of which would be in central and western states (Figure 6). Even a small, 15\% increase in irrigation in warm-temperate-dry climates of China would entail a further $0.2 \mathrm{Tg}$ of lost grain due to ozone (Figure 8). Added losses associated with increased irrigation would also occur in temperate and tropical-dry climates of other major producers such as Russia, Argentina, Australia, India and Kazakhstan, where irrigation is currently used only sparingly. Furthermore, yield losses due to ozone would increase by up to $50 \%$ if irrigation use were to be expanded in countries where food demand outweighs supply and substantial yield increases will be needed to mitigate import dependence (e.g. Ethiopia, Tanzania, South Africa, Figures 6 and 8). The intensification of ozone effects due to increased irrigation usage would be most pronounced in dry climates where less than $25 \%$ of the grid square is currently irrigated, with small added yield penalties still occurring where irrigation usage is $75 \%-100 \%$ (Figure S8). In contrast, added losses due to enhanced irrigation in moist climates would only be pronounced where less than $10 \%$ of the grid square is currently irrigated.

\section{DISCUSSION}

By modelling the stomatal uptake of ozone on a global scale, our results estimate that the current global wheat yield penalty from ozone pollution is a mean of $9.4 \%$ for $2010-2012$. This corresponds to $85 \mathrm{Tg}$ of lost grain per year, or losses of $\$ 24.2$ billion dollars per 

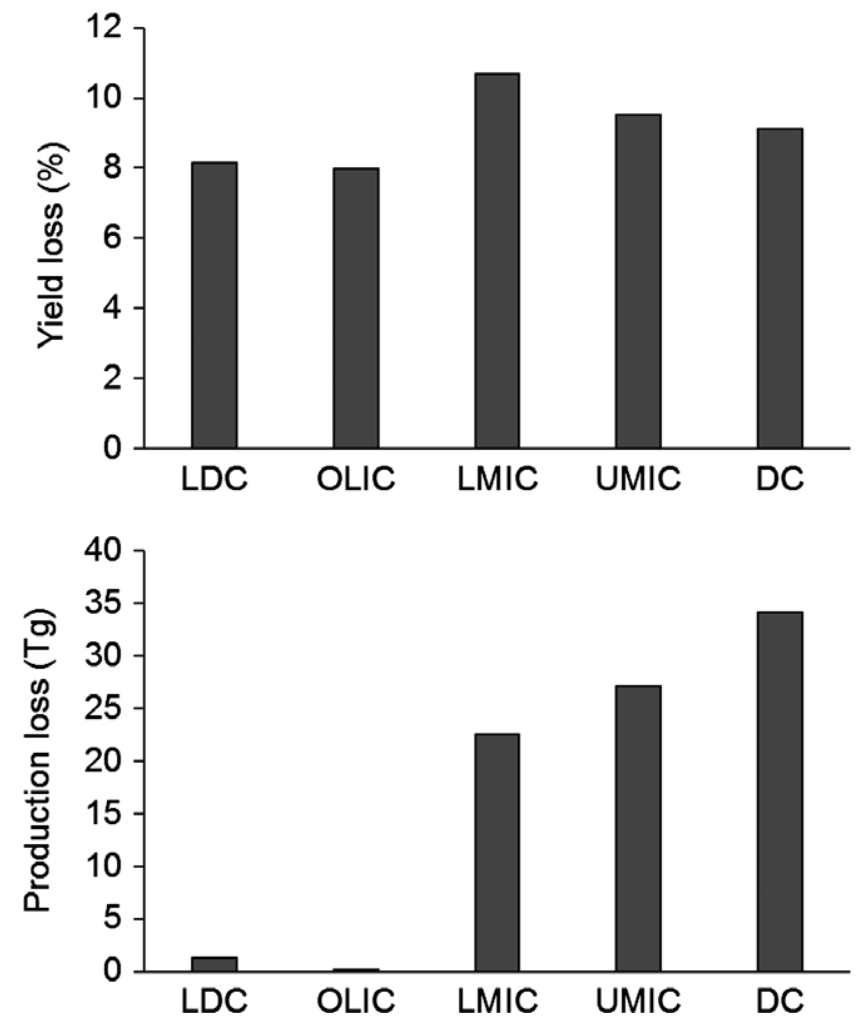

FIGURE 4 (a) Yield loss and (b) production loss (Tg) by country category, calculated using $\mathrm{POD}_{3} \mathrm{IAM}$ (see Figure 1) and averaged over 2010-2012. Countries have been assigned by the Organisation for Economic Co-operation and Development (OECD) Development Assistance Committee (DAC) into the following categories receiving Official Development Assistance (ODA): Least Developed Countries (LDC); Other Low Income Countries (OLIC); Lower Middle Income Countries and Territories (LMIC); and Upper Middle Income Countries and Territories (UMIC). The countries included in these categories are listed in OECD (2017), with their category added to Table S2. For comparison, effects of ozone on wheat yield are also shown for developed countries (DC), assumed here to be all other countries that are not included in the ODA recipients list

year at the mean global market price of $\$ 285$ per $\mathrm{Mg}$ for 2010 2012 (FAOSTAT). The only studies available that could be used to validate this figure show that the benefit of reducing ozone to preindustrial levels by filtration in field-based OTCs is in the range 8\%-9\%, averaged over nine countries (Pleijel, 2011; Pleijel et al., 2018). As these countries represent North America, Europe and Asia, it gives confidence that the mean global yield loss estimated in our study was comparable to the yield benefit found by reducing the ozone concentration at crop canopy height by an average of $62 \%$ by charcoal filtration. In addition, estimated yield losses for wheat in our study were comparable to yield losses attributed to ozone for maize $(10 \%)$ and higher than those for soybean $(5 \%)$ in regression analysis of historical yield data (McGrath et al., 2015). Further confidence in our analysis was gained from good agreement between measured and modelled ozone concentrations from sites around the world, and between our stomatal conductance modelling and annual data for the ratio of actual-to-potential evapotranspiration in wheatgrowing grid cells of the United States.

For the first time, this study compared the effects of ozone in DC that export $42 \%$ of their wheat grain with effects in countries receiving ODA that rely largely on home-grown wheat, exporting only $0.7 \%, 0.4 \%, 6.0 \%$ and $8.9 \%$ of production for LDC, OLIC, LMIC and UMIC respectively (Mean of 2010-2012, FAOSTAT). The combined production losses for countries receiving ODA of $51 \mathrm{Tg}$ was roughly $50 \%$ higher than those estimated for DC (34 Tg), providing support for our first hypothesis. Given that the demand for wheat is increasing at twice the rate in developing than developed countries (Shiferaw et al., 2013), then these losses due to ozone may reduce the likelihood of achieving the UN SDG 2 of securing food supplies and ending hunger by 2030 , especially in UMICs (e.g. China) and LMICs (e.g. India and Pakistan). This situation may be further exacerbated by breeding initiatives that favour increased stomatal conductance (Lobell \& Gourdji, 2012; Roche, 2015) that may be inadvertently increasing ozone uptake and effect on wheat, as newer varieties with higher stomatal conductance tend to be more sensitive to ozone, in part due to higher uptake of the pollutant (Biswas et al., 2009).

In this study, we found that the greatest yield losses are in the warm-temperate-moist, tropical-moist and tropical-wet climates of the $\mathrm{NH}$ and tropical-moist and -wet climates of the $\mathrm{SH}$. Under these conditions, stomatal uptake of ozone is often maximized and mean yield losses per climatic zone of $12 \%-17 \%$ and $9 \%-11 \%$ are

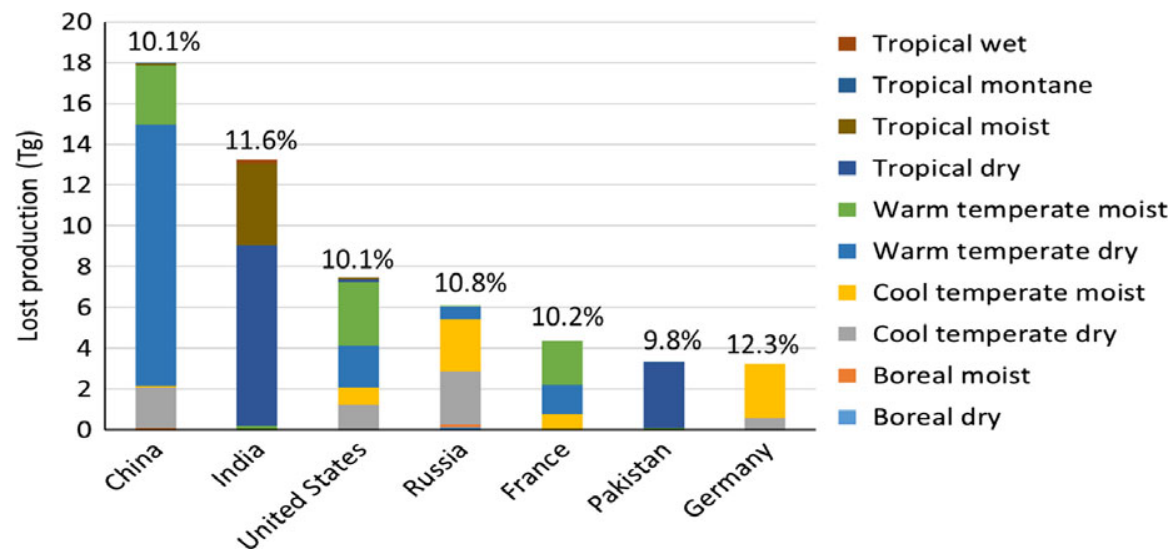

FIGURE 5 Production losses in wheat due to ozone for the seven most affected countries. Values are sums of production losses per $1^{\circ} \times 1^{\circ}$ grid cell calculated using production data and irrigation weighted $\mathrm{POD}_{3} \mathrm{IAM}$ (see legend for Figure 1 for explanation) within each climatic zone. The mean percentage yield loss per country is provided above each bar 


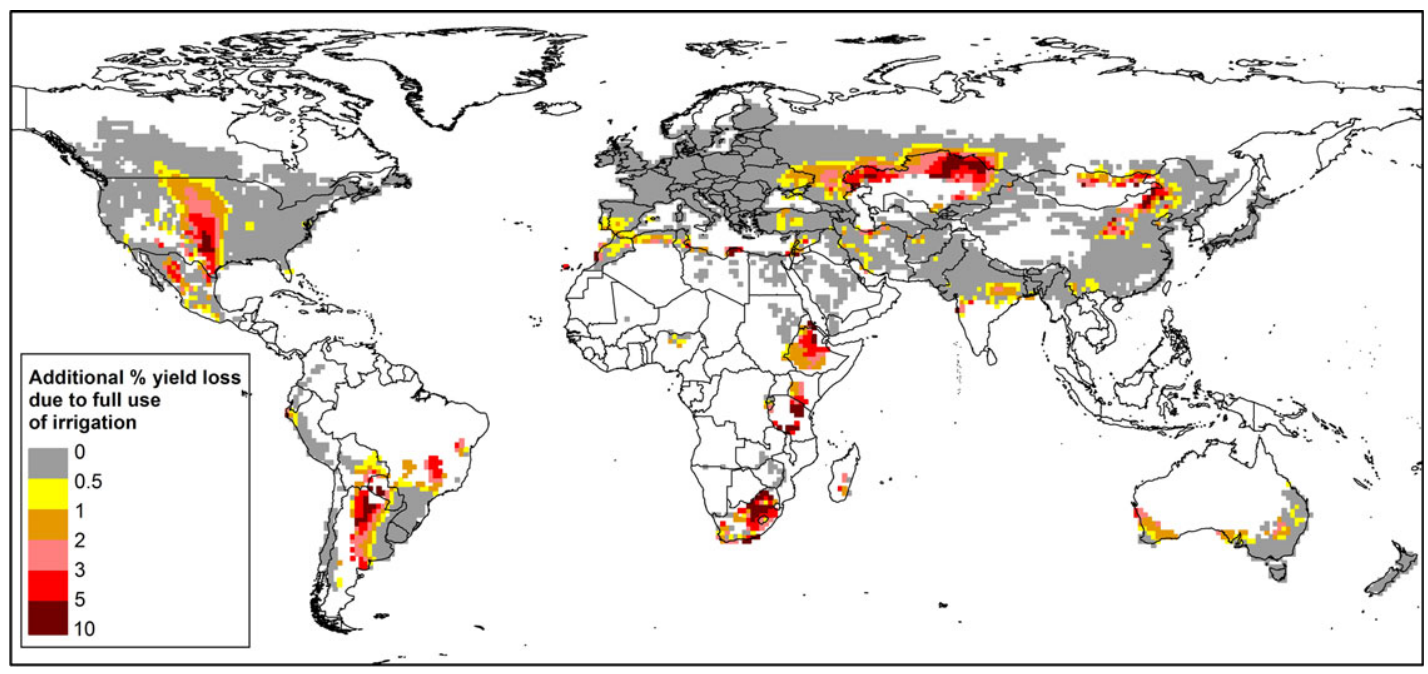

FIGURE 6 The effects of removing soil moisture limitation of stomatal conductance on ozone-induced yield loss by assuming that irrigation can be used as needed, presented as the added \% yield loss due to ozone if irrigation is increased from current usage to $100 \%$ for each grid cell. Yield losses with current irrigation usage are presented in Figure $1 \mathrm{f}$. Note: The values presented are per $1^{\circ} \times 1^{\circ}$ grid cell where the wheat production exceeds $500 \mathrm{Mg}$ and are averaged for 2010-2012

estimated for the $\mathrm{NH}$ and $\mathrm{SH}$, respectively. Interestingly, we also showed that in drier climates where irrigation is in use, yield losses can be in the same range as in moist climates, highlighting the importance of soil moisture as a factor influencing the extent of ozone uptake and subsequent yield reduction. For example, 67\%$99 \%$ of the production losses estimated for India, China and Pakistan were in tropical-dry and warm-temperate-dry climates where $78 \%$ 93\% of wheat-producing areas are irrigated. Of the countries with the highest production losses due to ozone, only in SW Russia was there a significant portion of a country's lost production in drier climates $(43 \%$ for temperate-cool-dry) where irrigation usage was limited (13\%).

Climatic zone impacts were also apparent when comparing estimations based on AOT40 or M7 with those based on $\mathrm{POD}_{3} \mathrm{IAM}$. For example, in the United States, the area of greatest concern switched from the temperate-dry climates of the western states that had the highest ozone concentrations to temperate-moist climates in eastern

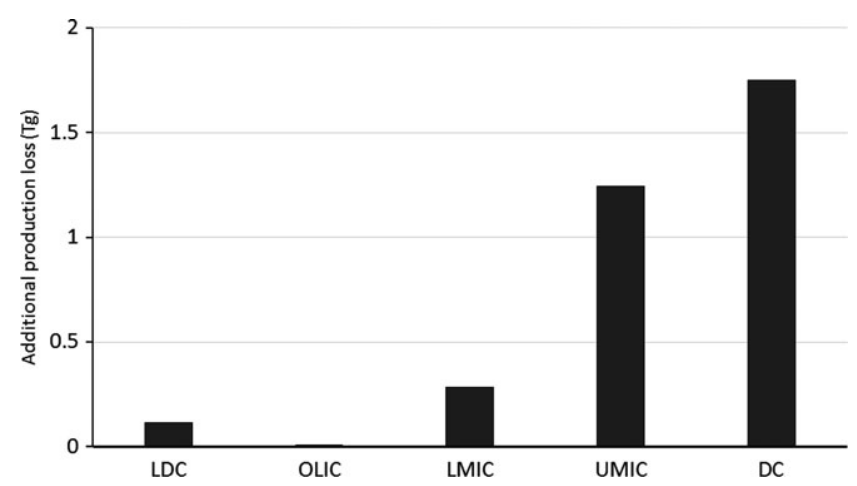

FIGURE 7 Additional lost production due to ozone, assuming $100 \%$ irrigation, presented by country category. See Figure 4 legend for key to county groupings states with more moderate concentrations, but higher $\mathrm{POD}_{3} \mathrm{IAM}$ values. Similar changes in areas of greatest concern are apparent when comparing with other spatial assessments based on ozone concentration. For example, our $\mathrm{POD}_{3} \mathrm{IAM}$ modelling estimated that the areas of highest risk were further south in China and further north in India than those estimated using AOT40 and M7 by Van Dingenen et al. (2009). While our concentration-based analysis showed similar areas being at risk in North America and Europe as those identified by Tai and Val Martin (2017), our stomatal uptake approach showed some spatial similarities and some differences to their partial derivative linear regression analysis of wheat yield data over an 18-year period. Their study showed high potential sensitivity of wheat to ozone along the United States-Canada border in an area where our study also predicted relatively high production losses. Here, low-moderate ozone concentrations coincide with climatic and soil moisture conditions that are highly conducive to stomatal uptake of ozone. In most other areas of the United States, their analysis including only ozone and heat as explanatory factors, found no significant trends over an 18-year period. We suggest that their lack of significance for these areas may in part be due to the omission of soil moisture as an explanatory factor - seen in this study to have a large modifying effect on wheat yield response to ambient ozone. This study also diverged from the first stomatal uptake-based assessment for India and China by Tang et al. (2013), whose spatial distribution of flux-based ozone risk is indeed closer to that of the concentration-based risks estimated in this study. This difference between the two studies could be attributed to the omission of soil moisture constraint on ozone uptake in Tang et al. (2013), and provides further support to the importance of soil water regime in the estimation of ozone risk.

This study also explored the consequences of a frequently discussed adaptation pathway for maintaining or increasing wheat production in future years: expansion of irrigation infrastructure and 

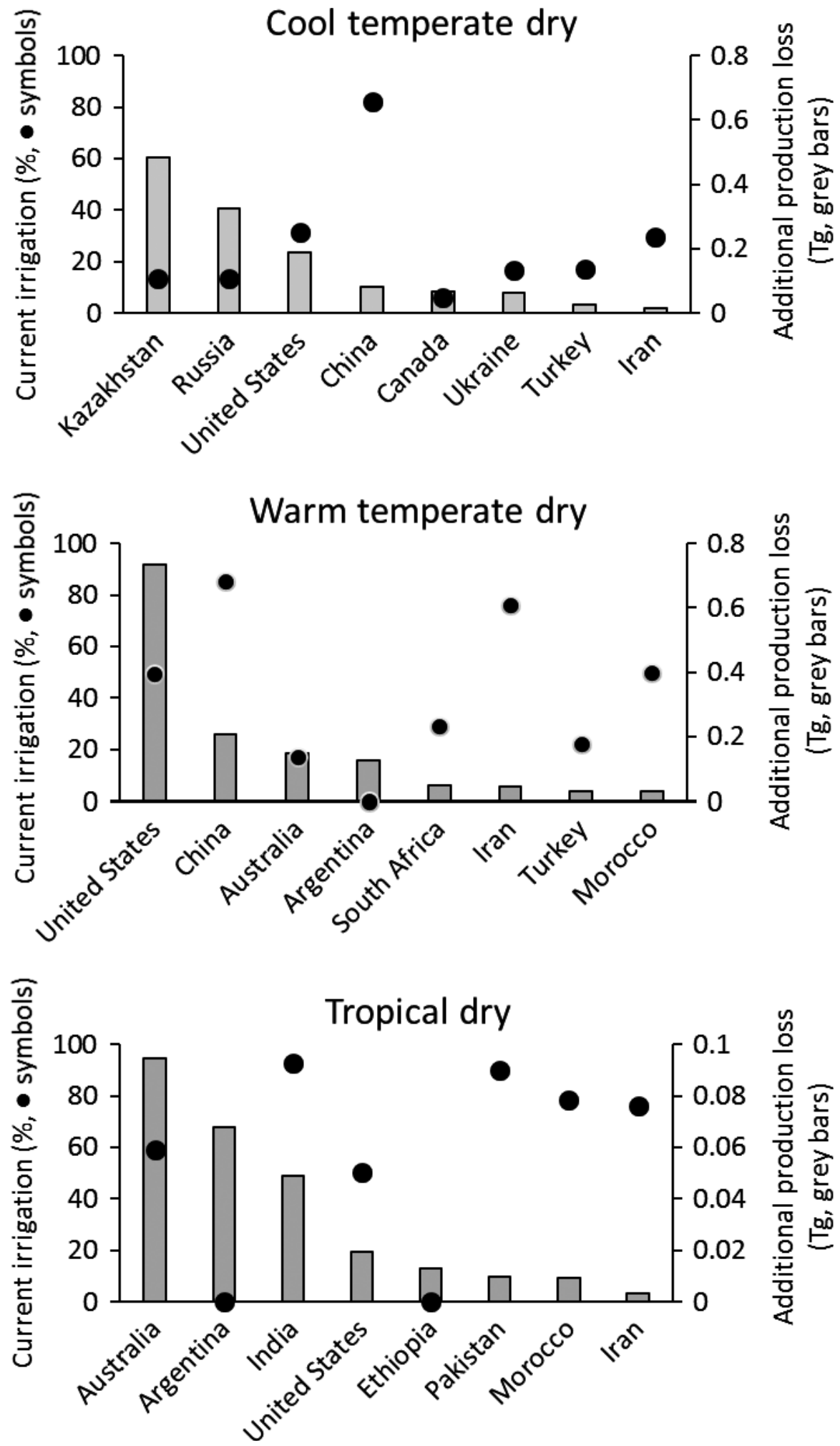

FIGURE 8 Additional wheat production losses associated with expansion of irrigation in dry climatic zones. The figure shows the percentage irrigation currently in use in each country (black filled circles) together with the additional production losses if irrigation were increased to $100 \%$ (grey bars) for (a) cool-temperate-dry, (b) warm-temperate-dry and (c) tropical-dry climatic zones. Values are means for 2010 2012, are calculated using $\mathrm{POD}_{3} \mid \mathrm{AM}$ and are shown for the eight most affected countries per climate zone usage (Balkovič et al., 2014; Jägermeyr et al., 2016; Tanaka et al., 2015). As a first step, we determined the potential added negative effects of ozone on wheat production if irrigation water is supplied whenever needed by removing the limitations due to soil moisture on ozone uptake. This relatively simple approach did not include the effects of irrigation-induced changes in wheat microclimate such as changes in VPD, heat and ozone fluxes (Tuovinen, Emberson, \& Simpson, 2009) on ozone uptake. On the evidence provided here, we argue that discussion of the benefits of added irrigation usage should take into account the potential negative effects of ozone uptake in countries and regions where the pollutant is prevalent. For example, in China, India, Germany and Pakistan where it is predicted 
that current wheat yields could be maintained in a future climate by use of new heat tolerant varieties and increasing the ratio of irrigated: unirrigated land by $50 \%$ (Tanaka et al., 2015), we suggest that crop yield could be reduced by an average of $9.5 \%-12.6 \%$ by ozone pollution if soil moisture is nonlimiting, outweighing some of the added benefits. Our analysis also shows that expanding irrigation usage to $100 \%$ in India and China as suggested in Tanaka et al. (2015) as a way to maintain wheat yields may increase yield losses due to ozone from $7.5 \%-15 \%$ to $11.5 \%-25 \%$ in the major wheatgrowing areas of these countries under current ozone levels, with effects potentially even higher as concentrations rise in coming decades (Wild et al., 2012). As well as reducing grain availability, such additional yield losses would also result in wasted fertilizer usage due to reduced fertilizer efficiency (Broberg, Uddling, Mills, \& Pleijel, 2017) and unproductive use of water, energy and labour, all of which are in short supply in many of these areas. In Argentina, one of the top 15 wheat producers and identified as having potential for expansion of irrigation (Jägermeyr et al., 2016), we have shown that full use of irrigation would result in a further $0.2 \mathrm{Tg}$ of lost grain and increase yield loss due to ozone from $5.6 \%$ to $7.8 \%$. In contrast, yield losses in Pakistan, where irrigation usage is already nearly $90 \%$, would only increase by a small amount $(0.01 \mathrm{Tg})$ if irrigation was used in all wheat-growing areas, as currently unirrigated areas in the NW tend to have lower ozone concentrations. In summary, when we compare our results with studies that identify regions where there is scope for increasing yield by irrigation expansion and improved water management, we predict that as much as one-third of the yield benefits of added irrigation could potentially be lost due to ozone pollution.

This analysis has compared the current effects of ozone against preindustrial ozone to give an indication of the extent of the negative effects of the pollutant under current climates. To facilitate comparisons, we have not taken into account that $\mathrm{CO}_{2}$ concentrations were also lower in preindustrial times which could have increased stomatal conductance for C3 plants by 20\%-30\% (Lammertsma et al., 2011; Purcell et al., 2018). While additional increases in $\mathrm{CO}_{2}$ by the end of the century might reduce stomatal conductance further (Purcell et al., 2018), complex interactions and feedbacks suggest that the predicted compensation for ozone effects is not supported by field evidence in C3 crops (Ainsworth, Yendrek, Sitch, Collins, \& Emberson, 2012; Mills et al., 2016). Indeed, site specific predictions for Europe indicate that the stomatal uptakebased risk of ozone damage may remain more or less the same as the effects of the combination of climate change, rising $\mathrm{CO}_{2}$ and rising $\mathrm{O}_{3}$, balance each other out (Klingberg, Engardt, Uddling, Karlsson, \& Pleijel, 2011). As well as increases in ozone on a global scale due to increased precursor emissions and long-range transport (Wild et al., 2012), reduced stomatal uptake of ozone under rising $\mathrm{CO}_{2}$ will also lead to increased ambient ozone concentrations, further reducing the compensatory effects of rising $\mathrm{CO}_{2}$ (Ainsworth et al., 2012).

Although recognized as a modifying factor that may be as, or more, important than effects of future changes in rainfall (Lobell \& Asseng, 2017), ozone is rarely included in either statistical or process-based modelling of current or future crop yields (e.g. Challinor et al., 2009; Lobell \& Asseng, 2017; Lobell \& Gourdji, 2012). There are several possible reasons for this. Firstly, the negative effects of the pollutant are not being recognized outside the ozone effects community. This is surprising given that the magnitude of effects reported here and elsewhere (e.g. Avnery et al., 2011a, 2011b; Van Dingenen et al., 2009) is in the same range as losses predicted for other effects of climate change. For example, a $6 \%$ decrease in wheat yield per $1^{\circ} \mathrm{C}$ rise in temperature is a cause for concern at the global scale (Asseng et al., 2013; Liu et al., 2016), with larger detrimental effects predicted at country scales (e.g. India, Lobell, Sibley, \& Ortiz-Monasterio, 2012; and Australia, Asseng, Foster, \& Turner, 2011). The second reason could be a lack of availability of accessible ozone or ozone stomatal uptake data, also highlighted in Lobell and Asseng (2017) as a contributing factor. This situation is now changing. A new initiative, the International Global Atmospheric Chemistry (IGAC) Global Tropospheric Ozone Assessment Report (TOAR), for the first time has brought together all publically available ozone data into one online easily searchable global database (Schultz et al., 2017; and http://www.igacproject.org/activi ties/TOAR). The TOAR study also includes an analysis of vegetation metrics, including AOT40 for wheat, from over 3300 vegetated sites in 44 countries presented as 15- and 20-year trends and current values, averaged for 2010-2014 (Mills et al., 2018). Furthermore, gridcell modelled values for ozone metrics are available for the EMEP grid at http://www.emep.int/mscw/mscw_data.html. A second reason could be a lack of collation of process-effects data in suitable format for process-based modelling which is currently being addressed (Emberson et al., 2018), including initiatives involving the AgMIP modelling community (Agricultural Model Intercomparison and Improvement Community; http://www.agmip.org/). Lastly, it is possible that some earlier concentration-based studies that have estimated relatively large effects of ozone in some regions (e.g. $17.5 \%$ to $55 \%$ yield losses estimated for India by Burney \& Ramanathan, 2014; Ghude et al., 2014; Avnery et al., 2011a, 2011b) may have inadvertently hindered acceptance within the agricultural community as the values may be higher than expected by agronomists. The new stomatal uptake-based method presented here, supported by field-based ozone filtration experiments from around the world, could provide the impetus for renewed interest in inclusion of ozone in crop yield predictive modelling.

In conclusion, our results indicate that the negative effects of ozone on wheat yield need to be mitigated in order to help close current yield gaps and achieve the UN SDG 2 of providing food security and eradicating hunger by 2030 (UN, 2016). Negative effects on wheat production in countries receiving ODA total $50 \%$ more than those in DC, meaning that both within-country production and imports will be impacted. Importantly, we also show that the benefits of water management practices and crop breeding strategies designed to increase yield potential by increasing carbon capture in wheat (Hawkesford et al., 2013; IFPRI, 2016; Jägermeyr et al., 2016; Mueller et al., 2012; Roche, 2015; Tanaka et al., 2015) may not be as pronounced as anticipated owing to the effects of co- 
occurring uptake of ozone pollution. Ozone impacts on yield might be mitigated by both (i) exploiting the genetic variation in ozone resistance in wheat cultivars in breeding programmes using approaches discussed recently for rice (Frei, 2015), and (ii) developing management strategies that protect against ozone damage (Wilkinson et al., 2012). Ultimately, though, the largest benefit would accrue from global-scale international efforts to reduce the emissions of ozone precursors, with co-benefits for the production of other staple food crops known to be sensitive or moderately sensitive to ozone (e.g. maize, soybean and rice (Mills et al., 2007) as well as for human health, ecosystems and climate (UN SDGs 3, 15 and 13, United Nations Sustainable Development Goals (2016)).

\section{ACKNOWLEDGEMENTS}

We thank the Natural Environment Research Council (NERC projects NEC05574 and NEC06476) for financial support and the Adlerbertska Foundation for supporting this study by funding Gina Mills' guest professorship at the University of Gothenburg (NERC project NEC05831). This work has been partially funded by EMEP under UNECE, and the EU project ECLAIRE (project no. 282910). Computer time for EMEP model runs was supported by the Research Council of Norway through the NOTUR project EMEP (NN2890K) for CPU.

\section{DATA ACCESSIBILITY}

The Supporting Information provides the National average crop yield losses calculated using M7, AOT40 and POD3IAM, and grid square values for ozone metrics for the LRTAP region can be downloaded from http://www.emep.int/mscw/mscw_data.html.

\section{CONFLICT OF INTEREST}

The authors declare no competing interests.

\section{ORCID}

Gina Mills iD http://orcid.org/0000-0001-9870-2868

Fernando Jaramillo (iD http://orcid.org/0000-0002-6769-0136

Elena Paoletti iD http://orcid.org/0000-0001-5324-7769

\section{REFERENCES}

Ainsworth, E. A. (2016). Understanding and improving global crop response to ozone pollution. The Plant Journal, 90, 886-897.

Ainsworth, E. A., Yendrek, C. R., Sitch, S., Collins, W. J., \& Emberson, L. D. (2012). The effects of tropospheric ozone on net primary productivity and implications for climate change. Annual Review of Plant Biology, 63, 637-661. https://doi.org/10.1146/annurev-arplant-042110103829

Amante, C., \& Eakins, B. W. (2009). ETOPO1 1 Arc-Minute Global Relief Model: Procedures, Data Sources and Analysis. NOAA Technical Memorandum NESDIS NGDC-24. National Geophysical Data Center,
NOAA. https://doi.org/10.7289/v5c8276m (downloaded May 4, 2016).

Asseng, S., Ewert, F., Rosenzweig, C., Jones, J. W., Hatfield, J. L., Ruane, A. C., ... Wolf, J. (2013). Uncertainty in simulating wheat yields under climate change. Nature Climate Change, 3, 827-832. https://d oi.org/10.1038/nclimate1916

Asseng, S., Foster, I., \& Turner, N. C. T. (2011). The impact of temperature variability on wheat yields. Global Change Biology, 17, 997-1012. https://doi.org/10.1111/j.1365-2486.2010.02262.x

Avnery, S., Mauzerall, D. L., Liu, J., \& Horowitz, L. W. (2011a). Global crop yield reductions due to surface ozone exposure: 1. Year 2000 crop production losses and economic damage. Atmospheric Environment, 45, 2284-2296. https://doi.org/10.1016/j.atmosenv.2010.11. 045

Avnery, S., Mauzerall, D. L., Liu, J., \& Horowitz, L. W. (2011b). Global crop yield reductions due to surface ozone exposure: 2. Year 2030 potential crop production losses and economic damage under two scenarios of $\mathrm{O}_{3}$ pollution. Atmospheric Environment, 45, 2297-2309. https://doi.org/10.1016/j.atmosenv.2011.01.002

Balkovič, J., van der Velde, M., Skalský, R., Xiong, W., Folberth, C., Khabarov, N., ... Obersteiner, M. (2014). Global wheat production potentials and management flexibility under the representative concentration pathways. Global and Planetary Change, 122, 107-121. https://doi.org/10.1016/j.gloplacha.2014.08.010

Biswas, D. K., Xu, H., Yang, J. C., Li, Y. G., Chen, S. B., Jiang, C. D., . . Jiang, G. M. (2009). Impacts of methods and sites of plant breeding on ozone sensitivity in winter wheat cultivars. Agriculture, Ecosystems \& Environment, 134, 168-177. https://doi.org/10.1016/j.agee.2009.06.009

Brisson, N., Gate, P., Gouache, D., Charmet, G., Oury, F. X., \& Huard, F. (2010). Why are wheat yields stagnating in Europe? A comprehensive data analysis for France. Field Crops Research, 119, 201-212. https://doi.org/10.1016/j.fcr.2010.07.012

Broberg, M., Uddling, J., Mills, G., \& Pleijel, H. (2017). Fertilizer efficiency in wheat is reduced by ozone pollution. Science of the Total Environment, 607-608, 876-880. https://doi.org/10.1016/j.scitotenv.2017. 07.069

Büker, P., Morrissey, T., Briolat, A., Falk, R., Simpson, D., Tuovinen, J. P., ... Emberson, L. D. (2012). $\mathrm{DO}_{3} \mathrm{SE}$ modelling of soil moisture to determine ozone flux to forest trees. Atmospheric Chemistry and Physics, 12, 5537-5562. https://doi.org/10.5194/acp-125537-2012

Burney, J., \& Ramanathan, V. (2014). Recent climate and air pollution impacts on Indian agriculture. Proceedings of the National Academy of Sciences of the United States of America, 111, 16319-16324. https://d oi.org/10.1073/pnas.1317275111

Challinor, A. J., Ewert, F., Arnold, S., Simelton, E., \& Fraser, E. (2009) Crops and climate change: Progress, trends, and challenges in simulating impacts and informing adaptation. Journal of Experimental Botany, 60, 2775-2789. https://doi.org/10.1093/jxb/erp062

Cooper, O. R., Parrish, D., Ziemke, J., Balashov, N. V., Cupeiro, M., Galbally, I. E., ... Zbinden, R. M. (2014). Global distribution and trends of tropospheric ozone: An observation-based review. Elementa: Science of the Anthropocene, 2, 000029. https://doi.org/10.12952/journal.el ementa.000029

ECMWF. European Centre for Medium-Range Weather Forecasts European Centre for Medium-Range Weather Forecasts. Retrieved from http:// www.ecmwf.int/ (accessed 2016).

Emberson, L. D., Ashmore, M. R., Simpson, D., Tuovinen, J. P., \& Cambridge, H. M. (2001). Modelling and Mapping Ozone Deposition in Europe. Water, Air, and Soil Pollution, 130, 577-582. https://doi.org/ 10.1023/A:1013851116524

Emberson, L. D., Pleijel, H., Ainsworth, E. A., van den Berg, M., Ren, W., Osborne, S., ... Van Dingenen, R. (2018). Ozone effects on crops and consideration in crop models. European Journal of Agronomy, (accepted). 
ETOPO1. Global Relief Model. Retrieved from https://www.ngdc.noaa. gov/mgg/global/global.html (accessed 2015).

FAOSTAT. Food and agriculture division of the United Nations statistics division. Retrieved from http://faostat3.fao.org/home/E (accessed 2016).

Frei, M. (2015). Breeding of ozone resistant rice: Relevance, approaches and challenges. Environmental Pollution, 197, 144-155. https://doi. org/10.1016/j.envpol.2014.12.011

Fuhrer, J. (1994). The critical level for ozone to protect agricultural crops - An assessment of data from European open-top chamber experiments. In J. Fuhrer \& B. Achermann (Eds.), Critical Levels for Ozone. UNECE Workshop Report, 42-57.

GAEZ. Global Agro-ecological Zones v3.0. Retrieved from http://www.gae z.iiasa.ac.at/ (accessed 2015)

GAW. World Data Centre for Greenhouse Gases. Retrieved from http:// ds.data.jma.go.jp/gmd/wdcgg/ (accessed 2015)

Ghude, S. D., Jena, C., Chate, D. M., Beig, G., Pfister, G. G., Kumar, R., \& Ramanathan, V. (2014). Reductions in India's crop yield due to ozone. Geophysical Research Letters, 41, 5685-5691. https://doi.org/10. 1002/2014GL060930

Grünhage, L., Pleijel, H., Mills, G., Bender, J., Danielsson, H., Lehmann, Y., ... Bethenod, O. (2012). Updated stomatal flux and flux-effect models for wheat for quantifying effects of ozone on grain yield, grain mass and protein yield. Environmental Pollution, 165, 147-157. https://doi.org/10.1016/j.envpol.2012.02.026

Hawkesford, M. J., Araus, J.-L., Park, R., Calderini, D., Miralles, D., Shen, T., ... Parry, M. A. (2013). Prospects of doubling global wheat yields. Food and Energy Security, 2, 34 48. https://doi.org/10.1002/fes3.15

Intergovernmental Panel on Climate Change (2006). IPCC Guidelines for National Greenhouse Gas Inventories, Volume 4. Retrieved from http:// www.ipcc-nggip.iges.or.jp/public/2006gl/vol4.html

International Food Policy Research Institute (2016). 2016 Global food policy report. Washington, DC: International Food Policy Research Institute. https://doi.org/10.2499/9780896295827

Jägermeyr, J., Gerten, D., Schaphoff, S., Heinke, J., Lucht, W., \& Rockström, J. (2016). Integrated crop water management might sustainably halve the global food gap. Environmental Research Letters, 11, 025002. https://doi.org/10.1088/1748-9326/11/2/025002

Joint Research Centre. Climatic zones. Retrieved from http://eusoils. jrc.ec.europa.eu/projects/RenewableEnergy/ (accessed 2015).

Klingberg, J., Engardt, M., Uddling, J., Karlsson, P. E., \& Pleijel, H. (2011). Ozone risk for vegetation in the future climate of Europe based on stomatal ozone uptake calculations. Tellus A, 63, 174-187. https://d oi.org/10.1111/j.1600-0870.2010.00465.x

Klingberg, J., Karlsson, P. E., Karlsson, G. P., Hu, Y., Chen, D., \& Pleijel, H. (2012). Variation in ozone exposure in the landscape of southern Sweden with consideration of topography and coastal climate. Atmospheric Environment, 47, 252-260. https://doi.org/10.1016/j.atmose nv.2011.11.004

Lammertsma, E. I., de Boer, H. J., Dekker, S. C., Dilcher, D. L., Lotter, A. F., \& Wagner-Cremer, F. (2011). Global $\mathrm{CO}_{2}$ rise leads to reduced maximum stomatal conductance in Florida vegetation. Proceedings of the National Academy of Sciences of the United States of America, 108, 4035-4040. https://doi.org/10.1073/pnas.1100371108

Liu, B., Asseng, S., Müller, C., Ewert, F., Elliott, J., Lobell, D. B., ... Zhu, Y. (2016). Similar estimates of temeperature impacts on global wheat yield by three independent methods. Nature Climate Change, 6, 1130-1136. https://doi.org/10.1038/nclimate3115

Lobell, B. D., \& Asseng, S. (2017). Comparing estimates of climate change impacts from process-based and staistical crop models. Environmetal Research Letters, 12, 015001. https://doi.org/10.1088/1748-9326/aa 518 a

Lobell, D. B., \& Gourdji, S. M. (2012). The Influence of Climate Change on Global Crop Productivity. Plant Physiology, 160, 1686-1697. https://doi.org/10.1104/pp.112.208298
Lobell, B. D., Sibley, A., \& Ortiz-Monasterio, J. I. (2012). Extreme heat effects on wheat senescence in India. Nature Climate Change, 2, 186 189. https://doi.org/10.1038/nclimate1356

Loibl, W., Winiwarter, W., Kopsca, A., Zufger, J., \& Baumann, R. (1994). Estimating the spatial distribution of ozone concentrations in complex terrain. Atmospheric Environment, 28, 2557-2566.

LRTAP Convention (2017). Chapter 3: Mapping Critical Levels for Vegetation. LRTAP Convention Modelling and Mapping Manual. Retrieved from http://icpvegetation.ceh.ac.uk/

McGrath, J. M., Betzelberger, A. M., Wang, S., Shook, E., Zhu, X. G., Long, S. P., \& Ainsworth, E. A. (2015). An analysis of ozone damage to historical maize and soybean yields in the United States. Proceedings of the National Academy of Sciences of the United States of America, 112(46), 14390-14395. https://doi.org/10.1073/pnas. 1509777112

Mills, G., Buse, A., Gimeno, B., Bermejo, V., Holland, M., Emberson, L., \& Pleijel, H. (2007). A synthesis of AOT40-based response functions and critical levels of ozone for agricultural and horticultural crops. Atmospheric Environment, 41, 2630-2643. https://doi.org/10.1016/j.a tmosenv.2006.11.016

Mills, G., Harmens, H., Wagg, S., Sharps, K., Hayes, F., Fowler, D., ... Davies, B. (2016). Ozone impacts on vegetation in a nitrogen enriched and changing climate. Environmental Pollution, 208, 898908. https://doi.org/10.1016/j.envpol.2015.09.038

Mills, G., Hayes, F., Simpson, D., Emberson, L., Norris, D., Harmens, H., \& Büker, P. (2011). Evidence of widespread effects of ozone on crops and (semi-)natural vegetation in Europe (1990-2006) in relation to AOT40- and flux-based risk maps. Global Change Biology, 17, 592613. https://doi.org/10.1111/j.1365-2486.2010.02217.x

Mills, G., Pleijel, H., Malley, C. S., Sinha, B., Cooper, O., Schultz, M. G., ... Xu, X. (2018). Tropospheric Ozone Assessment Report: Present day tropospheric ozone distribution and trends relevant to vegetation. Submitted to Elementa: Science of the Anthropocene.

Monteith, J. L. (1965). Evaporation and environment. Symposium of the Society of Experimental Biologists, 19, 205-224.

Mu, Q., Zhao, M., \& Running, S. W. (2011). Improvements to a MODIS global terrestrial evapotranspiration algorithm. Remote Sensing of Environment, 115, 1781-1800. https://doi.org/10.1016/j.rse.2011. 02.019

Mueller, N. D., Gerber, J. S., Johnston, M., Ray, D. K., Ramankutty, N., \& Foley, J. A. (2012). Closing yield gaps through nutrient and water management. Nature, 490, 254-257. https://doi.org/10.1038/nature 11420

Myneni, R., Knyazikhin, Y., \& Park, T. (2015). MOD15A2H MODIS Leaf Area Index/FPAR 8-Day L4 Global $500 \mathrm{~m}$ SIN Grid V006. NASA EOSDIS Land Processes DAAC. Retrieved from https://doi.org/10. 5067/MODIS/MOD15A2H.006 (Terra)

OECD (2017). Organisation for Economic Cooperation and Development Development Assistance Committee List of recipients of Official Development Assistance. Retrieved from http://www.oecd.org/dac/stats/dac list.htm (Accessed 2017).

Pleijel, H. (2011). Reduced ozone by air filtration consistently improved grain yield in wheat. Environmental Pollution, 159, 897-902. https://d oi.org/10.1016/j.envpol.2010.12.020

Pleijel, H., Broberg, M. C., Uddling, J., \& Mills, G. (2018). Current surface ozone concentrations significantly decrease wheat growth, yield and quality. Science of the Total Environment, 613-614, 687-692. https://doi.org/10.1016/j.scitotenv.2017.09.111

Purcell, C., Batke, S. P., Yiotis, C., Caballero, R., Soh, W. K., Murray, M., \& McElwain, J. C. (2018). Increasing stomatal conductance in response to rising atmospheric $\mathrm{CO}_{2}$. Annals of Botany. https://doi.org/10. 1093/aob/mcx208

Roche, D. (2015). Stomatal conductance is essential for higher yield potential of C3 Crops. Critical Reviews in Plant Sciences, 34, 429-453. https://doi.org/10.1080/07352689.2015.1023677 
Royal Society (2008). Ground-level ozone in the 21st century: Future trends, impacts and policy implications. Science Policy Report, 15(08), 1-133.

Sacks, W. J., Deryng, D., Foley, J. A., \& Ramankutty, N. (2010). Crop planting dates: An analysis of global patterns. Global Ecology and Biogeography, 19, 607-620.

Schultz, M., Akimoto, H., Bottenheim, J., Buchmann, B., Galbally, I. E., Gilge, S., ... Zellweger, C. (2015). The Global Atmosphere Watch reactive gases measurement network. Elementa: Science of the Anthropocene, 3, 000067. https://doi.org/10.12952/journal.elementa. 000067, 2015.

Schultz, M. G., Schröder, S., Lyapina, O., Lyapina, O., Cooper, O., Galbally, I., ... Zhiqiang, M. A. (2017). Tropospheric Ozone Assessment Report: Database and metrics data of global surface ozone observations. Elementa: Science of the Anthropocene, 5, 58. https://doi.org/10.1525/ elementa. 244

Shiferaw, B., Smale, M., Braun, H.-J., Duveiller, E., Reynolds, M., \& Muricho, G. (2013). Crops that feed the world 10. Past successes and future challenges to the role played by wheat in global food security. Food Security, 5, 291-317. https://doi.org/10.1007/s12571-013-0263-y

Simpson, D., Arneth, A., Mills, G., Solberg, S., \& Uddling, J. (2014). Ozone - the persistent menace: Interactions with the $\mathrm{N}$ cycle and climate change. Current Opinion in Environmental Sustainability, 9-10, 9-19. https://doi.org/10.1016/j.cosust.2014.07.008

Simpson, D., Ashmore, M. R., Emberson, L., \& Tuovinen, J. P. (2007). A comparison of two different approaches for mapping potential ozone damage to vegetation. A model study. Environmental Pollution, 146, 715-725. https://doi.org/10.1016/j.envpol.2006.04.013

Simpson, D., Benedictow, A., Berge, H., Bergström, R., Emberson, L. D., Fagerli, H., ... Wind, P. (2012). The EMEP MSC-W chemical transport model - technical description. Atmospheric Chemistry and Physics, 12, 7825-7865. https://doi.org/10.5194/acp-12-7825-2012

Simpson, D., Tsyro, S., \& Wind, P. (2015). Updates to the EMEP MSC-W model. Transboundary particulate matter, photo-oxidants, acidifying and eutrophying components. EMEP Status Report 1/2015, 129-138.

Soja, G., Barnes, J. D., Posch, M., Vandermeiren, K., Pleijel, H., \& Mills, G. (2000). Phenological weighting of ozone exposures in the calculation of critical levels for wheat, bean and plantain. Environmental Pollution, 109, 517-524. https://doi.org/10.1016/S0269-7491(00)00055-5

Tai, A. P. K., \& Val Martin, M. (2017). Impacts of ozone air pollution and temperature extremes on crop yields: Spatial variability, adaptation and implications for future food security. Atmospheric Environment, 169, 11-21. https://doi.org/10.1016/j.atmosenv.2017.09.002

Tanaka, A., Takahashi, K., Masutomi, Y., Hanasaki, N., Hijioka, Y., Shiogama, H., \& Yamanaka, Y. (2015). Adaptation pathways of global wheat production: Importance of strategic adaptation to climate change. Scientific Reports, 5, 14312. https://doi.org/10.1038/sre p14312

Tang, H., Takigawa, M., Liu, G., Zhu, J., \& Kobayashi, K. (2013). A projection of ozone-induced wheat production loss in China and India for the years 2000 and 2020 with exposure-based and flux-based approaches. Global Change Biology, 19, 2739-2752. https://doi.org/ 10.1111/gcb.12252

Teixeira, E., Fischer, G., van Velthuizen, H., van Dingenen, R., Dentener, F., Mills, G., ... Ewert, F. (2011). Limited potential of crop management for mitigating surface ozone impacts on global food supply. Atmospheric Environment, 45, 2569-2576. https://doi.org/10.1016/j.a tmosenv.2011.02.002

Tuovinen, J.-P., Emberson, L., \& Simpson, D. (2009). Modelling ozone fluxes to forests for risk assessment: Status and prospects. Annals of Forest Science, 66, 401-415. https://doi.org/10.1051/forest/2009024

United Nations Sustainable Development Goals (2016). Retrieved from https://sustainabledevelopment.un.org/?menu=1300

Van Dingenen, R., Dentener, F. J., Raes, F., Krol, M. C., Emberson, L., \& Cofala, J. (2009). The global impact of ozone on agricultural crop yields under current and future air quality legislation. Atmospheric Environment, 43, 604-618. https://doi.org/10.1016/j.atmosenv.2008. 10.033

Wild, O., Fiore, A. M., Shindell, D. T., Doherty, R. M., Collins, W. J., Dentener, F. J., ... Zuber, A. (2012). Modelling future changes in surface ozone: A parameterized approach. Atmospheric Chemistry and Physics, 12, 2037-2054. https://doi.org/10.5194/acp-12-2037-2012

Wilkinson, S., Mills, G., Illidge, R., \& Davies, W. J. (2012). How is ozone pollution reducing our food supply? Journal of Experimental Botany, 63, 527-536. https://doi.org/10.1093/jxb/err317

\section{SUPPORTING INFORMATION}

Additional supporting information may be found online in the Supporting Information section at the end of the article.

How to cite this article: Mills G, Sharps K, Simpson D, et al. Ozone pollution will compromise efforts to increase global wheat production. Glob Change Biol. 2018;24:3560-3574. https://doi.org/10.1111/gcb.14157 